\title{
Notes Towards A Definition of Politics
}

\author{
JAMES ALEXANDER
}

\begin{abstract}
Politics has been defined in different and contradictory ways in the last century or so. If politics is to be a single subject of study then contradictory theories should be capable of being related together. In this article I argue that they can be related in terms of what I call the Aristotelian criterion. The article is in four parts. Firstly, I discuss the problem of defining politics; secondly, I introduce the criterion; thirdly, I consider five modern theories of politics (those of Arendt, Oakeshott, Collingwood, Schmitt and Rancière) in relation to the criterion; and fourthly, I use the criterion to put forward an original and capacious definition of politics. ${ }^{1}$
\end{abstract}

\section{The Problem of Politics}

The problem of defining politics has arisen in its modern form because for a century we have been unable to define it in terms of the state. It was common in the nineteenth century for philosophers to define the state as the political society and the political society as the state - so that politics was just a function of the state. ${ }^{2}$ But with the separation of the concept of politics from the concept of the state in the early twentieth century, and the abandonment of such circular definitions, we entered a situation in which politics could be used as an independent term, as one capable of extension by metaphor, so that any situation or association or relation or status could be political. Defining just what we mean by politics has been difficult

1 This paper was written in Bilkent between 2010 and 2013. It is the fourth recension of arguments read originally by Edward Castleton, Stephen Clark, Janet Coleman, John Dunn, Efraim Podoksik, Christopher Ryan, Ulrich Steinvorth, Lars Vinx and William Wringe, and subsequently by readers for the British Fournal of Political Science, the Review of Politics and Political Theory. The difficulty throughout has been to balance the philosophical systematisation of the meaning of politics and the historical recognition of the varieties of the meaning of politics.

2 See Henry Sidgwick, The Development of a European Polity (London: Macmillan, 1903), 25-26. See also J.R. Seeley, Introduction to Political Science (London: Macmillan, 1896), and Bernard Bosanquet, The Philosophical Theory of the State 4th ed. (London: Macmillan, 1923).

doi:10.1017/S0031819113000855

(C) The Royal Institute of Philosophy, 2014

First published online 6 February 2014

Philosophy 892014 
ever since. ${ }^{3}$ The concept of the state, whatever its drawbacks, kept politics in harness. Without the state, politics often seems as if it is anything or everything. As Bartelson puts it, 'if politics is boundless by virtue of being bounded only by itself, everything human can at least hypothetically be subsumed under this concept'. But this has a corollary: 'If politics potentially encompasses everything, it can itself be but nothing.' ${ }^{4}$ To speak more plainly, the absence of attempts to define politics in the last forty or fifty years is a sign of a certain embarrassment about how to deal with definition in a situation where the word 'politics' can be used to mean almost anything.

Yet the twentieth century was the political century par excellence. There was far greater discussion of politics (or the category of the political) than ever before. And undoubted classics were written, at least before late in the century - Schmitt's Concept of the Political, Collingwood's New Leviathan, Arendt's The Human Condition, and Oakeshott's On Human Conduct. These are classics partly because of the brilliance of their definitions of politics. But each of these definitions of politics, including the other one I consider here, the one developed by Rancière, is a partial one. There is certainly no obvious way that one could reconcile any of them. It was while considering this problem - the problem of reflecting on politics in terms of a series of brilliant but partial definitions - that I began to see that the only way to reconcile them would be to take a step backwards and consider whether there was something common to all of them, some sort of a criterion which would enable us to explain why politics is politics and not something else, and why all these theories of politics are theories of politics and not of something else.

Fortunately, there is such a criterion, and it is one which was evident to Aristotle at the beginning of our tradition of political reflection. It is the identification of this criterion in this article which makes it possible - however controversial this may seem - to propose something like a complete definition of politics.

Politics is of course a confused and confusing subject. Most writers in the last thirty or so years have therefore put forward hopeful and partial definitions of politics or, in an attempt to be inclusive, summarised disagreements between various different hopeful and

3 For discussions of difficulty, see John Dunn, The Cunning of Unreason: Making Sense of Politics (London: Harper Collins, 2000), 9-12 and Raymond Geuss, History and Illusion in Politics (Cambridge: Cambridge University Press, 2001), 14-15.

4 Jens Bartelson, The Critique of the State (Cambridge: Cambridge University Press, 2001), 64. 
partial definitions of politics. ${ }^{5}$ No one now dares to write about politics in any other way. The recently republished book What is Politics? can be used to indicate some of the confusion which currently surrounds the subject, because in it we find as many answers to the question as there are contributors to the book. The editor appears to be unaware that the definitions assembled in his book contradict his own introductory definition. He suggests that politics is 'all the activities of co-operation, negotiation and conflict, within and between societies, whereby people go about organising the use, production or distribution of human natural or other resources in the course of the production and reproduction of their biological and social life.' 6 This is a good definition of its type: but it lacks two things. The first is order: more or less everything is tumbled together and called politics. The second is the ideal: there is no sense that politics is anything other than a trivial set of activities, and certainly no sense that it has the importance Aristotle attributed to it. Presumably this sort of uninspiring but unarguable definition is meant to exist alongside the many inspiring and arguable definitions which are found in the rest of the book. But I think this is the sort of confusion which is inevitable if we take it as an axiom that 'political philosophers offer no single answer to the question of what politics is'. ${ }^{7}$ As a description, this may well be right. As prescription, it is of course wholly wrong. The political philosophers I depend on in this article offered single answers to the question of what politics is. And so, in a slightly different register, do I.

5 See Agnes Heller, 'On the Concept of the Political Revisited' in D. Held (ed.) Political Theory Today (Oxford: Polity, 1991), 330-44, Chantal Mouffe, The Return of the Political (London: Verso, 1993), Bonnie Honig, Political Theory and the Displacement of Politics (New York: Cornell University Press, 1993), Noel O'Sullivan, 'Difference and the Concept of the Political in Contemporary Political Philosophy', Political Studies 45 (1997): 739-54, and Elizabeth Frazer, 'Political theory and the boundaries of politics', in D. Leopold and M. Stears (eds) Political Theory: Methods and Approaches (Oxford: Oxford University Press, 2008), 171-95. John Dunn in The Cunning of Unreason suggests that hopeful definitions are inadequate. For a rare attempt to offer an inclusive rather than hopeful definition see the nonetheless still unsystematic extension of Weber's definition of politics in Raymond Geuss, History and Illusion in Politics (Cambridge: Cambridge University Press, 2001), 14-15.

6 Adrian Leftwich (ed.), What is Politics? The Activity and Its Study (Cambridge: Polity, 2004), 103.

7 Adam Swift, 'Political Philosophy and Politics', in ibid., 135-46, at 135. 


\section{James Alexander}

There are, broadly, four responses to the question. Firstly, there are those who avoid it, as Rawls did, by writing 'political philosophy' without even mentioning 'politics' at all. ${ }^{8}$ For a long time this sleight of hand has been common in much academic play, but there is now a growing sense that it is unacceptable. ${ }^{9}$ Secondly, there are those who pretend to face the problem only to say that politics cannot be defined in any formal sense. 'All political concepts are inherently contestable,' we are told by one writer, 'since disagreement over the meaning of a concept is what makes it political.' ${ }^{10} \mathrm{Or}$, as another writer tells us, politics is simply a 'floating signifier' which 'rival political forces' struggle to 'fix'. ${ }^{11}$ This is surely just a subtle or sly way of avoiding the question. By its own argument, it is contestable, and so refutes itself. Thirdly, and more respectably, there are those who offer more or less casual definitions of politics as they go along. But these definitions are also, on examination, completely contradictory. If one scholar can be found to say politics is ' $x$ ', there is always another to say it is 'not-x'. If one says politics is 'conflicts, antagonisms, relations of power, forms of subordination and repression', 12 then another says it is 'making, applying, interpreting or

8 Rawls stands at the head of the tradition which writes about political philosophy without mention of politics. For Rawls on the 'political' (which means, more or less, the 'legal') see John Rawls, Fustice as Fairness: A Restatement ed. Erin Kelly (London: Belknap Press, 2001), 182. For works on political philosophy which do not discuss politics see Will Kymlicka, Contemporary Political Philosophy: An Introduction (Oxford: Clarendon Press, 1990), Raymond Plant, Modern Political Thought (Oxford: Blackwell, 1991), Jonathan Wolff, An Introduction to Political Philosophy (Oxford: Oxford University Press, 1996), and Dudley Knowles, Political Philosophy (London: Routledge, 2001).

9 See Chantal Mouffe, 'Rawls: Political Philosophy Without Politics', in The Return of the Political (London: Verso, 1993), 41-59, and Raymond Geuss, 'Neither History Nor Praxis', in Outside Ethics (Princeton: Princeton University Press, 2005).

10 John Hoffman, Introduction to Political Theory (Harlow: Pearson, 2006), xxxiv.

11 Ernesto Laclau in R. Goodin and P. Pettit (eds) Companion to Contemporary Political Philosophy (Oxford: Blackwell, 1993), 435. This seems to be the concept of politics which, usually defined negatively against what it is not, was restored to radical thought by Laclau and Chantal Mouffe in Hegemony and Social Strategy: Towards a Radical Democratic Politics (London: Verso, 1985).

12 Chantal Mouffe, The Return of the Political (Verso, 1993), 49. Cf. politics as 'striving for power' in Max Weber, 'The Profession and 
enforcing the law' ${ }^{13}$ If one says it is 'voting, law-making, pressuregroup activity, and "governing" in the conventional sense', ${ }^{14}$ then another says it is 'some form of individual or collective action that disrupts ordinary states of affairs, normal life, or routine patterns of behaviour or government' ${ }^{15}$ 'There seems to be no limit to the number of partial or casual and ultimately contradictory definitions it is possible to find in the standard literature. ${ }^{16}$ But fourthly, we have those who have attempted to come up with an original and complete theory of politics. In this essay I consider five such theories. They are worth serious attention, even though, as we shall see, they also contradict each other.

As far as I know, no one has yet asked why it is that the most interesting definitions of politics proposed in the last century contradict each other.

It is not enough for us to acknowledge that there are contradictions. We must make sense of them, for it is possible that contradiction is constitutive of politics. And if this is so, then the fact that any definition of politics can be contradicted is a problem for every single definition of politics, no matter how great, original or suggestive it is. Perhaps it is relevant to say at this point that I have had more difficulty in shaping this theory than any other I have yet attempted. This of course may be because there has been something intractably contradictory about politics ever since it was first discussed in antiquity in relation to the Greek polis. Even in classical times there were several ambiguities about politics. The first was that it could refer to both the study of the polis and the activities appropriate to it. The second was that it could refer to both ruling the polis and deliberating in the polis. The third was that it could refer to both the ideal polis and the actual polis. Another complication was added later when political terminology was adopted in European languages

Vocation of Politics' (1919) in P. Lassman and R. Spiers (eds) Political Writings (Cambridge: Cambridge University Press, 1994), 311.

13 D.D. Raphael, Problems of Political Philosophy (London: Duckworth, 1990), 31.

14 Norman P. Barry, An Introduction to Modern Political Theory (London: Macmillan, 1989), 15.

15 The Oxford Handbook of Political Theory (eds). J.S. Dryzek, B. Honig and A. Phillips (Oxford: Oxford University Press, 2006), 8.

${ }_{16}$ For others see Sheldon Wolin, Vision of Politics: Continuity and Innovation in Western Political Thought (Princeton: Princeton University Press, 2006), 11, and Bernard Crick, In Defence of Politics 4th ed. (London: Penguin, 1992), 21. 
after William of Moerbeke's translation of Aristotle. For now it was used for the dark practices or 'politicks' associated with raison d'état or reason of state. If in classical times politics had seemed the highest form of existence, or one of the highest (beside the contemplative life), it often seemed, from the sixteenth century onwards, one of the lowest. ${ }^{17}$ Politics continued to have two aspects, ideal and actual: but these two aspects could not be as easily reconciled for Hobbes, Locke and Rousseau as they had been for Plato and Aristotle - except by force, which usually meant the fiat of the state. ${ }^{18}$ For the next three centuries politics was defined in terms of the state. It was only when politics was separated from the state that the problem of defining politics arose. This happened in the twentieth century.

In the 1920s, beginning with Schmitt and Collingwood, there were attempts to define politics (or the category of the political) afresh; and to some extent the period between, say, 1920 and 1970 could perhaps now be considered - despite those old sayings about the 'death of political philosophy'19 - the era of the great attempt by philosophers to consider politics as a thing in itself. Certainly since Oakeshott's $O n$ Human Conduct in 1975 there have been few, if any, attempts to think through politics. There has been an occasional interesting suggestion in the writings of rather quixotic French philosophers. But, in general, most of what we have had (in the universities) since, say, 1971 , is concern on the practical side with so-called empirical politics and on the philosophical side with so-called normative theories which appear to justify involvement in the practical world. It seems to me that some other approach is necessary. Almost a century ago Collingwood suggested that philosophy 'brings us to know in a different way things which we already know in some way'. ${ }^{20}$ It does so by offering us a definition: not a 'mere' definition, but what he

17 Maurizio Viroli, 'The Revolution in the Concept of Politics', Political Theory 3 (1992), 473-95.

18 For typical uses of 'political' in relation to the state see John Locke, Two Treatises of Government, II, 2-3, in ed. Peter Laslett (Cambridge: Cambridge University Press, 1988), 268, Jeremy Bentham, A Fragment on Government (1776) ed. J.H. Burns and H.L.A. Hart (Cambridge: Cambridge University Press, 1988), 40, and John Austin, The Province of Furisprudence Determined (1832) ed. H.L.A. Hart (London: Weidenfeld and Nicolson, 1954), 194.

19 See Andrew Vincent, The Nature of Political Theory (Oxford: Oxford University Press, 2004), 91-95.

20 R.G. Collingwood, Essay on Philosophical Method (Oxford: Clarendon Press, 1933), 161. 
called 'an extended and reasoned definition'. ${ }^{21}$ It is such an extended and reasoned definition that I hope to offer in this article.

There are three further things to say about politics before I begin. First of all, politics is an activity. Collingwood first stated in the 1920 s that politics should be considered 'under the category of action', and I think everyone now accepts this. ${ }^{22}$ We see this if we compare a typical definition of politics from the late nineteenth century ('the system of relations which ought to be established among the persons governing, and between them and the governed, in a society composed of civilized men, as we know them') ${ }^{23}$ with a typical definition of politics from the late twentieth century ('the activity through which people make, preserve and amend the general rules under which they live'). ${ }^{24}$ I do not think more has to be said about this here. Secondly, politics is emphatically not to be identified with rule. We want to avoid the sort of facile definition that simply associates politics with government, any sort of government. It is obviously a waste of the word politics to use it simply to mean the struggle for status in court, country or the corridors of power. Politics is not mere 'politicks'. I do not think much has to be said about this either. ${ }^{25}$ But, thirdly, and most importantly, politics is something to do with rule. Dunn has observed that 'the least controversial feature of [Aristotle's] viewpoint today is his presumption that politics is

21 Ibid., 96.

22 R.G. Collingwood, 'Political Action' (1928) in D. Boucher (ed.) Essays in Political Philosophy (Oxford: Clarendon Press, 1989), 92-109, at 92.

23 Henry Sidgwick, The Elements of Politics 4th ed. (London: Macmillan, 1919), 15.

24 Andrew Heywood, Politics (London: Palgrave, 2007), 21.

25 This seems to be the view of certain 'defences' of politics written in imitation of Bernard Crick's famous book of 1962. I simply do not think this argument - made in Gerry Stoker, Why Politics Matters: Making Democracy Work (London: Palgrave Macmillan, 2006) and Matthew Flinders, Defending Politics: Why Politics Matters in the Twenty-First Century (Oxford: Oxford University Press, 2012) - is necessary. These books simply confuse two things they want to distinguish: politics and 'politicks'. Such books generate their energy through the confusion which follows when we at one and the same use the word politics to mean both the reality of rule and the ideal which complicates it. This confusion is embedded in our everyday language (where 'distrust of politicians' becomes 'dislike of politics', although it is nothing of the sort: we only distrust politicians because we expect good to come of politics). Nothing philosophical can be gained by simply accepting the confusion. 
inherently concerned with rule'. But since at least two of the theories considered in this essay (those of Arendt and Rancière) differ from the Aristotelian tradition at exactly this point, it is better to be more cautious and say that politics is always somehow related to rule (or, more strictly, to ruling and being ruled). ${ }^{26}$ This claim requires explanation, and I go on to explain it in the next section.

\section{The Aristotelian Criterion}

The argument here is that if we want to have a unified theory of politics we need one that can somehow bring together the very different theories of politics developed by some of the greatest and most original thinkers. To do this we have to establish a criterion that is external to any particular theory. This can no longer be the state, which in older thought supplied an external criterion for politics. For a century it has been obvious that it has to be something more fundamental than the state. I call this criterion the 'Aristotelian criterion'.

Aristotle had difficulties with politics, and I think his difficulties indicate something fundamental about the subject. In the Nicomachean Ethics he asked whether politike was the same as nomothetike or some sort of separate activity. ${ }^{27}$ It is worth quoting him in full:

Prudence [phronesis] is indeed the same quality of mind as Political Science [politike], though their essence is different. Of Prudence as regards the state, one kind, as supreme and directive, is called Legislative Science [nomothetike]; the other, as dealing with particular occurrences, has the name, Political Science [politike], that really belongs to both kinds. The latter is concerned with action [praktike] and deliberation [bouleutike]. ${ }^{28}$

'That really belongs to both kinds' is the Loeb translation. ${ }^{29}$ I take it that nomothetics is to do with ruling, whereas politics is something to do with ruling and yet also something not to do with ruling because it is to do with action and deliberation. I do not want to insist that this is

26 Dunn, op. cit. note 3, 15.

27 Aristotle, Nicomachean Ethics, $1141 \mathrm{~b}$ in the Loeb edition, ed. H. Rackham (Camb. Mass.: Harvard University Press, 1934), 347.

28 Ibid.

29 Compare Aristotle, Nicomachean Ethics trans. Terence Irwin (Indianapolis: Hackett, 1985), 159: 'That [properly] applies to both parts in common'. 
Aristotle's meaning, since I lack the necessary Greek. But it is evident to me that Aristotle is uneasy about terms that he cannot distinguish entirely. And it is this which seems to me to be the hint about how to proceed.

It certainly seems that politics has involved some sort of relation to rule ever since Aristotle. In the Politics he referred to what was even for him was the 'old saying' that it is impossible to be a good ruler unless one has been a good subject: so in the polis we must be able 'both to be ruled and to rule' (archesthai kai archein), and therefore we must all be 'rulers and ruled' (archonta kai archomena). ${ }^{30}$ Politics is certainly somehow concerned with - as we put it in English - 'ruling and being ruled'. But there has never been any consensus on what exactly the relation is between politics and 'ruling and being ruled'. Indeed, there has never been an exact consensus on what Aristotle meant by the phrase. ${ }^{31}$ It seems to me that part of the resonance of the phrase is in its suggestion that the conjunction kai ('and') transforms the meaning of the two opposed terms so that they become distinctively political. As a preliminary then:

THE ARISTOTELIAN CRITERION is that politics has some sort of relation to ruling and being ruled.

But how should this be understood? There is an ambiguity in the phrase 'ruling and being ruled'. It can simply mean ruling (on the one hand) and being ruled (on the other), as if they are together the sum of their parts; or it can mean ruling and being ruled combined in such a way that they are together more than the sum of their parts. It is the latter which is politics. Aristotle's enigmatic suggestion was that in politics we somehow or other come to rule ourselves - an idea certainly not present in the sum of ruling and being ruled. So it is desirable here to distinguish mere 'ruling and being ruled' from some intensified 'ruling-and-being-ruled'. Politics is more than the sum of ruling and being ruled. But it nonetheless has some relation to ruling and being ruled. I think that this can be made clear by distinguishing a ruling order from a political order:

RULING (and hence mere 'ruling and being ruled') postulates a hierarchical order in which ruler and ruled are distinguished; POLITICS (and hence 'ruling-and-being-ruled') postulates a

30 Aristotle, Politics 1277 b \& 1254a in op. cit. note 27, 192-3.

31 See Arendt, On Revolution (London: Penguin, 1990), 30-31, Michael Oakeshott, On Human Conduct (Oxford: Clarendon Press, 1975), 167 n. 1, and Dunn, op. cit. note 3, 30, for three different interpretations of what 'ruling and being ruled' means for the relation of politics and ruling. 


\section{James Alexander}

non-hierarchical order in which ruler and ruled are not distinguished.

This is a very important distinction. (It was not present in earlier versions of this argument, and, without it, the argument soon became confused.) For it makes it clear that politics and rule are in a sense antithetical: that, in Aristotle's words, politics and nomothetics are rival sciences. But when harnessed to the Aristotelian criterion the distinction makes it clear that although they are antithetical orders they are nonetheless orders which have some significant theoretical relation. Even though politics does not postulate a non-hierarchical order, it is only politics in so far as the non-hierarchical order it postulates is related to the hierarchical order of rule.

This is the central paradox of politics. Politics transforms ruling and being ruled so that becomes ruling-and-being-ruled. Or, in other words, politics sublates rule. As many know, 'sublate' is the English translation of a famous Hegelian term which means three things at the same time: to negate, assimilate and transform. This sort of language is objectionable to many. But such terminology, or something like it, is useful here in explaining even to those who dislike Hegel why politics is not a simple matter. Let me suggest the following image of how these orders relate. They are not to be identified with each other. Instead, they are like intersecting planes which come into contact. Imagine we have a lattice of atoms on the left, and another lattice of different atoms on the right: then we bring the two together to achieve some sort of reaction. Depending on the atoms involved, the variables of atomic energies, electric charge, distance and so on - and here, since I am not talking about scientific but political matters (the analogy should only be understood so far and no further) - they will react in different ways. This is the image I would like to use here: for my suggestion is that politics is an ordering system which, in theory, can be brought into some sort of relation with an ordering system of rule in order to see how they relate to each other. It is not identical with it, but can be brought into a more or less close interaction with it. Depending on the particular theory of politics (and this is why I will go on to consider five different theories below), there are different reactions: politics may become dominant, or remain recessive, or may transform the other order through identification, or it may destroy it, or be repelled, or pass by as if nothing has happened. The result, to use a physical term, may be isotropic, that is, atomically harmonious and fitting together in such a way that the result is stronger, or it may be 
anisotropic, that is, disharmonious in such a way that the result is weaker, or prone to sudden rupture.

This enables me to restate the Aristotelian criterion:

THE ARISTOTELIAN CRITERION is that politics is found when a non-hierarchical order (where there is no ruling and being ruled), or the idea of such an order, comes into relation with a hierarchical order (where there is ruling and being ruled), in such a way that the latter is understood in a way not possible were it to be understood in its own terms and is transformed in significance through the activity or the possibility of the activity called which is called political.

The transformation may be, so to speak, consecratory: politics may sanctify or authorise ruling and being ruled so it achieves an ideal or consummate form. Or it may be desecratory: politics may destroy ruling and being ruled and put something else, which is, of course, ideal, in its place. It is between these two possibilities of consecration and desecration that we find all the shades of political meaning which are familiar to anyone who studies actual politics.

\section{Five Classic Theories of Politics}

In this article it is unnecessary, and certainly not possible, to consider actual politics. ${ }^{32}$ But it is necessary to consider actual political theories to indicate why I suppose the Aristotelian criterion enables us to relate them to each other in such a way that we can explain why we recognise all of them to be distinctive theories of politics even though they contradict each other. Here I take five theories which were developed in the twentieth century, for the reason I suggested above: that it is only in this century that philosophers attempted to

32 About actual politics, it is perhaps relevant to say that I am no admirer of political science as such, agreeing more or less with what Oakeshott wrote about Lasswell in 1948 ('laboured analysis', 'childish examples', 'obscuring abstractions'). See Michael Oakeshott's review of The Analysis of Political Behaviour in The Concept of a Philosophical Furisprudence: Essays and Reviews 1926-1951 (Exeter: Imprint Academic, 2007), 220-1. As far as I know, the closest study of political events ever written is Cowling's historical trilogy about British politics in the late nineteenth and early to mid twentieth century (where there was sufficient archival material to sustain the closest possible analysis). See, for instance, the first of these: Maurice Cowling, 1867: Disraeli, Gladstone and Revolution (Cambridge: Cambridge University Press, 1967). 


\section{James Alexander}

make sense of politics in a way that did not depend on the polis, on theology or, most significantly, on the concept of the state. These five theories are miscellaneous, they have different concerns, and in the form in which the philosophers have left them they cannot be combined into one theory. But none can be ignored.

For Arendt, politics is an activity which is an end in itself. In her initial sketch of her theory, written in the late 1950s, and now published as The Promise of Politics, ${ }^{33}$ Arendt explains this view of politics:

The meaning of politics ... is that men in their freedom can interact with one another without compulsion, force, and rule over one another, as equals among equals, commanding and obeying one another only in emergencies - that is, in times of war - but otherwise managing all their affairs by speaking with and persuading one another. Politics ... is therefore centered around freedom, whereby freedom is understood negatively as not being ruling or being ruled, and positively as a space which can be created only by men and in which each man moves among his peers. ${ }^{34}$

In The Human Condition she clarifies the point that politics is not to be associated with ruling and being ruled. 'To be political, to live in a polis, mean[s] that everything [is] decided through words and persuasion and not through force and violence. In Greek self-understanding, to force people by violence, to command rather than to persuade, [are] prepolitical ways to deal with people characteristic of life outside the polis.' 35 Politics is therefore 'acting together and appearing in public, inserting ourselves into the world by word and deed, thus acquiring and sustaining our personal identity and beginning something entirely new'. ${ }^{36}$ Has there ever been a purer definition of politics? If Arendt is remembered for anything it should

33 Hannah Arendt, The Promise of Politics ed. Jerome Kohn (New York: Schocken, 2005). This book, written in the 1950s but not published then, was the initial sketch for The Human Condition, but it is a clearer statement of the thesis, even if sometimes less consistent about the separation of ruling and politics.

34 Ibid., 117.

35 Hannah Arendt, The Human Condition (Chicago: Chicago University Press, 1958), 26-7.

36 Hannah Arendt, 'Truth and Politics', in P. Laslett and W.G. Runciman (eds) Politics, Philosophy and Society: Third Series (Oxford: Basil Blackwell, 1967), 133. 
be this exquisite clarification, if also exaggeration, of one element of the Greek understanding of politics. ${ }^{37}$

Arendt was of course aware that most philosophers have associated rule and politics. But she thought this association was a 'degradation of politics at the hands of philosophy'. ${ }^{38}$

The greater part of political philosophy since Plato could easily be interpreted as various attempts to find theoretical foundations and practical ways for our escape from politics altogether. The hallmark of all such escapes is the concept of rule, that is, the notion that man can lawfully and politically live together only when some are entitled to command and the others forced to obey. The commonplace notion already to be found in Plato and Aristotle that every political community consists of those who rule and those who are ruled ... rests on a suspicion of action ... and arose from the earnest desire to find a substitute for action. ${ }^{39}$

If Plato was responsible for attempting to achieve fixity rather than fluidity in politics, so 'to a lesser degree' was Aristotle. ${ }^{40}$ As far as I know Arendt never wrote directly about the Aristotelian phrase 'ruling and being ruled', but there is a passage in On Revolution which suggests that she would have liked to suggest that it was a riddle which once resolved would eliminate rule from politics altogether. There she writes that the polis was originally 'a form of political organization in which the citizens live[d] together in conditions of no-rule, without a division between ruler and ruled'. Arendt depends on Herodotus, whose term isonomia, usually translated as 'equality before the law', she translates as 'no-rule', since 'the notion of rule' is 'entirely absent from it'. 'The point of Herodotus's equation of freedom with no-rule', she writes, 'was that the ruler himself was not free; by assuming the rule over others, he had deprived himself of those peers in whose company he would have been free.' ${ }^{41}$

37 It has received much criticism. See Bhikhu Parekh, Hannah Arendt and the Search for a New Political Philosophy (London: Macmillan, 1981), 52. See also Dunn, op. cit. note 3, 36.

38 Arendt, The Promise of Politics, op. cit. note 33, 135. Cf. The Human Condition, op. cit. note 35, 229-30.

39 Ibid., 222.

40 Ibid., 230.

41 Hannah Arendt, On Revolution (London: Penguin, 1990), 30-31, citing Herodotus, Histories, 3.83. 


\section{James Alexander}

Arendt's theory of politics is remarkable. But the second theory, Oakeshott's, though perhaps less bold, is equally original and equally exact. Arendt says that politics is separate from ruling and being ruled. Oakeshott argues, on the contrary, that politics cannot be separated from them. But he certainly does not think that politics can be identified with either of them. His suggestion is that politics should be understood as an activity which is reciprocal to rule without being the same as merely being ruled. Oakeshott shares Arendt's view that the Greek philosophers perhaps mistakenly encouraged us to identify politics and rule:

The common confusion between politics and rule is, in some respects, a legacy of the Aristotelian vocabulary, which has no word for 'civil' distinguished from 'political'. In this vocabulary politike stands for the art of caring for and bettering the public concern of a polis. And the somewhat hazy distinction between this and that of ruling is reflected in the equivocal character of the politikos, concerned (it would appear) both in politike and in ruling. But politeia is a deeply ambiguous word. It stands for that in terms of which a polites is related to his fellows (with perhaps an emphasis upon rules in their character as rules of recognition); it denotes the rule of a politikos distinguished from that of a master (despotes); and it designates the constitution of a particular kind of ruling authority. ${ }^{42}$

The word politeia was given a meaning it did not etymologically deserve. 'This somewhat confused usage, translated into Latin, later reappeared in such expressions as princeps politicus (Ptolemy of Lucca).' And after 'Sir John Fortescue identified the ruling authority in England of his time as dominium politicum et regale' it 'became a term of general commendation or of denigration. ${ }^{43}$ At first, if something was 'political' it was good; later, under the influence of Machiavelli, badly assimilated, it was bad.

In his lectures Oakeshott notes that for Aristotle 'political activity' was 'the activity of deciding things by deliberating and talking about them' ${ }^{44}$ If Arendt emphasizes the deliberative element of this while ignoring the decisive element, and if Schmitt, as we shall see, emphasizes the decisive element while ignoring the deliberative element, Oakeshott attempts to acknowledge the significance of both.

\footnotetext{
42 Oakeshott, On Human Conduct, op. cit. note 31, 167 n. 1.

43 Ibid., 167 n. 1.

44 Oakeshott, Lectures in the History of Political Thought (Exeter: Imprint Academic, 2006), 107.
} 
Politics, he says, requires firstly association and then the 'recognition of common customs or rules of conduct'. It is 'the activity in which a society deals with its diversities' - not, as Arendt would have it, the activity in which a society experiences its diversities. ${ }^{45}$ It therefore involves both deliberation and decision.

In On Human Conduct Oakeshott suggests that politics is related to rule, is in some sense reciprocal to it, but is not itself to be identified with either ruling or being ruled. It cannot be identified with being ruled, because being ruled is a passive, or incidental, state: the ruled acknowledge the rules by which they are ruled, and they do this whenever they act in accordance with rules. But 'being ruled' is not an activity. That is to say, no one acts in order to follow a rule: they act for some reason of their own, in accordance with rules. It is difficult to consider 'being ruled' as an activity - as the very passive nature of its verbal construction indicates. If politics is an activity, then it cannot be 'being ruled', which is a passivity.

So Oakeshott defines politics as the activity by which rulers and ruled (but not in their capacity as rulers or ruled) deliberate on the way they are ruled, and express their 'approval or disapproval' of rule. ${ }^{46}$ In Oakeshott's formulation, politics is the 'engagement of considering the desirability or otherwise of the conditions prescribed in a practice where the practice itself (and not any desire to procure a substantive satisfaction) is the terms of association and where these conditions are susceptible of deliberate change'. This is simpler than it sounds: 'This identification, of course, entails the rejection or putting-by of much that belongs to fashionable doctrine, but it is absolved from arbitrary conceit not only in returning the world (after an adventurous career) more nearly to its original meaning but in its connection with common usage. ${ }^{47} \mathrm{He}$ adds that all other uses of the term politics are 'metaphorical'. ${ }^{48}$

Politics is not a necessary element of historical human experience, then, as ruling and being ruled is, but a definite possibility within it. It is conducted in a different language to that of rule. While ruling is manifest in authoritative utterance, politics is manifest in

45

46 Ibid., 35.

Oakeshott, On Human Conduct, op. cit. note 31, 159.

47 Ibid., 161. Compare 'a concern with the conditions of an association in respect of their desirability or cogency', in Michael Oakeshott, 'The Vocabulary of a Modern European State' (1975), in L. O'Sullivan (ed.) The Vocabulary of a Modern European State (Exeter: Imprint Academic, 2008), 261

48 Oakeshott, On Human Conduct, op. cit. note 31, 162. 


\section{James Alexander}

persuasive utterance. This is why 'politics is categorically distinguished from ruling.' 49 Rulers may engage in politics, but they cease to be rulers when they engage in it. And in the same way, the ruled cease to be the ruled when they engage in it. Politics cannot, according to this definition, be revolutionary: it involves no subversion of the authority of rule: it is 'acquiescent and critical'. ${ }^{50}$ It exists alongside ruling and being ruled. Oakeshott agrees, therefore, with Arendt's view that politics implies equality whereas rule does not. But politics is not a primary activity: it is a secondary one, which is only possible when 'persons without authority' are able to approve or disapprove of rules, and to offer their opinions about the need to change or not change them. Politics is never so separate from rule that it is unconcerned with it. It is always 'public' in the sense that it is addressed to, or expressed in the hearing of, those who have authority to do what should be done. It is 'persons without authority ... negotiating with holders of authority'. ${ }^{51}$ This may be the most prosaic definition of politics of the five considered here: although it has its own poetry. It is not a bad account of what politics often seems to be in practice.

Instead of attempting to theorise politics, as Arendt and Oakeshott do, as if it is separate from ruling and being ruled, Collingwood suggests instead that it should be seen as the combination of them. Politics is neither mere ruling, nor mere being ruled, nor even something else entirely, but is ruling and being ruled combined together in such a way that they are transformed. Here it is necessary to see ruling and being ruled as more than the sum of their parts. If there is ruling, and being ruled, separately and then in sum, then this is an order, but it is not a political order. If ruling and being ruled are brought into harmony, then there is political order.

Politics for Collingwood is a fully reciprocal activity in which the apparent passivity of obeying laws is understood as in some sense an activity because ruling and being ruled are reciprocal aspects of the same activity. Being ruled is not something incidental but something fundamental: it is the way that the ruled contribute to a political

49 Ibid., 166. C.f. Oakeshott, 'The Vocabulary of a Modern European State', op. cit. note 47, 261: 'Rulers may deliberate desirabilities, they may make "political" utterances recommending what they have done or about to do in terms of its desirability, and they may babble; but none of this is "ruling".'

50 Oakeshott, On Human Conduct, op. cit, note 31, 164.

51 Ibid., 163. 
order. In an early essay Collingwood defines politics as 'the science of rightness or conformity to rule'. ${ }^{52}$ It follows that 'political action' is 'the making and obeying of laws' - the making and obeying, note 'essentially regulation, control, the imposition of order and regularity upon things'. And it follows from this that the political virtues are 'orderliness, regulation, submission'. ${ }^{53}$ Rulers and ruled are related in this activity. One the one hand there is 'the universal, law itself', manifest in the activity of rulers, and on the other there is 'the individual, the act of obeying law', manifest in the activity of the ruled. 'These are both actions. Law is not something that exists independently of an agent; it exists only in the act of positing it or affirming it.' And Collingwood claims that, philosophically, they are the same, no matter how different they seem in practice. This is not an empirical matter: philosophically, he argues, 'the two acts of making and obeying law are thus the universal and individual aspects of one and the same act, and their unity in that act is its rightness. ${ }^{54}$

The combination of ruling and being ruled in politics means that 'the political good is order as such'. It is both 'regulating and regulated life' ${ }^{55}$ It is therefore unintelligible if it is understood in terms of a separation of ruling and being ruled. Politics depends on the view that the state 'is within every one of us' ${ }^{56}$ For him, the state in his early writings he still uses this term - is not mere government: it is a totality in which subject and object are, in whatever sense, reconciled. And so politics is unlimited: it is not simply a matter of governmental rule, but is any activity associated with ruling and being ruled. 'The rules of a corporation, the statutes of a company, the regulations of a club, the routine of a family, are all political facts, and no less political are the rules which a man makes for his own guidance, and revises from time to time as occasion demands.' ${ }^{57}$ Even selfrule is political.

In his later writings Collingwood distances himself from the nineteenth-century concept of the state. In The New Leviathan he assumes that all humans are associated in community, and communities need to be ruled. But he distinguishes two types of rule: a

52 R.G. Collingwood, 'Politics' (1933), in Collingwood, op. cit. note 22, $118-123$, at 119 .

53 Collingwood, 'Political Action' (1928-29), in ibid., 92-109, at 96 \& 100.

54 Collingwood, 'Politics', in ibid., 119-20.

55 Collingwood, 'Political Action', in ibid., $100 \& 103$.

56 Ibid., 106.

57 Collingwood, 'Politics' (1929), in ibid., 110-17 at 114. 


\section{James Alexander}

community which rules itself is a 'society', and a community which needs to be ruled by something other than itself is a 'non-social community'. He calls the sort of rule found in the first 'immanent rule' and the sort of rule found in the second 'transeunt rule'. ${ }^{58} \mathrm{~A}$ society requires 'consciousness of joint free decision to undertake and share a certain action'. This is clearly ideal, as ideal as anything in Arendt. But, unlike Arendt, Collingwood supposes that such a society is not what we have in politics but is one of two extremes between which actual politics exists. And he attributes the discovery of this to Hobbes (which is why his book has the title it does).

What is a body politic? Is it, as the Greeks believed, a society of citizens corporately ruling themselves and having non-citizen dependants, wives, children, and so forth? or is it, as the Middle Ages thought, a non-social community, a human herd which strong men rule and good men would wish to rule well?

Hobbes said: 'It is both.' 59

Collingwood declares that Hobbes's discovery was a 'greater discovery than any other made in that science since perhaps the time of Aristotle' ${ }^{60}$ It is that 'a body politic is a dialectical thing', strung out between the classical and the medieval ideals. ${ }^{61}$ And this leads Collingwood to suggest his still unappreciated 'three laws of politics'. ${ }^{62}$ The first law is that 'a body politic is divided into a ruling class and a ruled class'; the second law is that 'the barrier between the two classes is permeable in an upward sense'; and the third law is that 'there is a correspondence between ruler and ruled.' This third means that the ruler 'must rule them in the way in which they will let themselves be ruled'. ${ }^{63}$ All of these laws are intended to elaborate the fundamental point which is that ruler and ruled are bound together in politics, and that politics is ruling and being ruled where 'ruling and being ruled' is more than the sum of its parts: that is, where ruling and being ruled are dialectically related. This is by some way the most idealistic (or Idealistic) definition of politics of the five sketched here.

58 R.G. Collingwood, The New Leviathan (Oxford: Clarendon Press, 1943), 138-40.

59 Ibid., 177-80.

60 Ibid., 180.

61 Ibid., 183.

62 Ibid., 189.

63 Ibid., 190. 
'One seldom finds', Schmitt writes, 'a clear definition of the political.' ${ }^{64}$ Schmitt's theory, the fourth, introduces a novelty. For he is not concerned with the definition of politics as such but with the definition of the rather confusing category of the political. He famously suggests that the core of the political is to be found not in any institution or relation, but in terms of the original necessity and perpetual possibility of making a decision about who is our friend and who is our enemy. Just as an ethical decision concerns the antithesis of good or evil, and an aesthetic decision concerns the antithesis of beautiful and ugly, so a political decision concerns the antithesis of friend and enemy. Schmitt himself observes that his definition is a definition 'in the sense of a criterion and not ... an exhaustive definition or one indicative of substantial content' ${ }^{65}$ So it is not intended to be a characterization of politics as such. It is an attempt to show what can be brought under the category of the political. Yet it is important to note that, unlike the previous theories, this theory takes it for granted that the political - and therefore also politics (as the activities which take place within the category of the political) - is not something posterior to ruling and being ruled but something prior to them.

Schmitt's antithesis of friend and enemy cuts across the antithesis of ruler and ruled. 'The autonomy of the political becomes evident by virtue of its being able to treat, distinguish and comprehend the friend-enemy antithesis independently of other antitheses.' 66 In fact, it ignores it, or treats it as a mere consequence. Schmitt's theory is concerned with decision, the fundamental decision which distinguishes friend and enemy. Arendt's theory, as we have seen, seems to ignore decisions, whereas Oakeshott's and Collingwood's theories recognize them, while suggesting that politics is either a response to a decision or a means by which it is made. But Schmitt's focus is wholly on this decision: so much so, that he is not particularly interested in how it is made, or by whom: whether by ruler or ruled does not matter. The decision is independent of ruling and being ruled. And even when it is made in a context in which there are rulers and ruled it is still more fundamental than the distinction between them. 'The rule of law', for instance, 'means nothing else than the legitimation of a specific status quo.' ${ }^{67}$

64 Carl Schmitt, The Concept of the Political (1932) trans. George Schwab (Chicago: University of Chicago Press, 1996), 20.

65 Ibid., 26.

66 Ibid., 27.

67 Ibid., 66. 
Politics, when Schmitt discusses it at all, is no more than the 'scramble for office', 'the politics of patronage' or 'party politics'. ${ }^{68}$ Any political act or event or relation or institution is derivative of the fundamental decision: it is either designated 'political' through an extension of meaning by analogy or metaphor, or, more concretely, called 'politics' because it is somehow attendant to this decision. So parliament and press can be considered political because they are derivative of or dependent on the ultimate political concern of deciding who is friend and who is enemy; but they are subversive of politics if they bring politics under their own category of communication or conversation. This explains why Schmitt is dismissive of 'banal forms of politics', in which 'the original friend-enemy grouping is only some sort of antagonistic moment, which manifests itself in all sorts of tactics and practices, competitions and intrigues, and the most peculiar manipulations' ${ }^{69}$

What we have here is a conception of politics in terms neither of rulers and ruled attempting to meet shared standards so that order can be achieved (as Collingwood suggests), nor of the ruled responding to attempts of the rulers to lay down standards by making judgements they make about how those standards affect the diversity of their interests (as Oakeshott suggests), and nor even of humans simply sharing their diversity (as Arendt suggests). What we have instead is the view that in any particular state, or body politic, rulers and ruled - and even those who would rather not rule or be ruled have to face the political imperative that a decision be made. The decision cuts across the lines of ruling and being ruled, of making and obeying laws. All Schmitt says about this decision is that it is made by the sovereign - 'he who decides on the exception'. ${ }^{70}$ This sovereign is independent of rulers and ruled. Yet even though this is so, the decision of the sovereign nonetheless has great political significance because it is manifest in a world where rulers and ruled exist.

The fifth and final theory, like Schmitt's, emphasizes discontinuity rather than continuity. Here politics is antithetical to ruling and being ruled, as it is for Arendt, but it is not a continual or necessary activity of the sort Arendt sketches. It is a momentary or disruptive activity. It is, moreover, not separate from ruling or being ruled, as politics is for Arendt, but is actively antagonistic to it. There is

68 Ibid., 32.

69 Ibid., 30.

70 Carl Schmitt, Political Theology: Four Chapters on the Concept of Sovereignty trans. George Schwab (Chicago: University of Chicago Press, 2005), 5. 
more than one major theorist who has explored this point of view, but it is stated most clearly in the writings of Rancière.

Politics is, according to this view, a revolt against ruling and being ruled. Rancière mentions Aristotle's vision of a 'pure politics', and is aware of Arendt's elevation of this into a 'way of life'. ${ }^{71}$ But, for Rancière, 'if we are to understand the originality of the Aristotelian formulation, banal representations of the doxa of parliamentary systems that invoke the reciprocity of rights and duties must be set aside'. Aristotle - and here Rancière agrees with Arendt - saw politics as 'reciprocity'. But 'ruling and being ruled' is 'something rather different to reciprocity'. In fact it 'is constituted by an absence of reciprocity'. ${ }^{72}$ And so it follows that politics is 'a break with the axiom of domination, that is, any sort of correlation between a capacity for ruling and a capacity for being ruled'. ${ }^{73}$

What we have here is the only definition of politics that actively opposes politics to ruling and being ruled. Politics only occurs, Rancière tells us, when the 'count of the uncounted' is 'identified with the whole community'. ${ }^{74}$ His name for everything concerned with the usual activity of ruling and being ruled is 'police', while 'politics' is the word for any activity which disrupts this activity. And this activity of politics is not a necessary one. 'Its existence is by no means necessary, but that it occurs as an always provisional accident within the history of forms of domination.' Or again: 'Politics is by no means a reality that might be deduced from the necessities leading people to gather in communities. Politics is an exception in relation to the principle according to which this gathering occurs. ${ }^{75}$ The distinction between police and politics is therefore that police is the part of those with a part - those who have agreed to share society so that some rule and some are ruled - while politics is 'a part of those without a part'. ${ }^{76}$ The meaning of the Aristotelian phrase is therefore that in politics there is a 'subject who "rules" by the very fact of having no qualifications to rule'. ${ }^{77}$

71 Jacques Rancière, 'Ten Theses on Politics', Dissensus: On Politics And Aesthetics, trans. Steven Corcoran (Continuum, 2010), 27-44, at 27. This summarises the argument developed first in Jacques Rancière, Disagreement: Politics and Philosophy, trans. Julie Rose (Minneapolis: University of Minnesota Press, 1999).

$\begin{array}{ll}72 & \text { Ibid., 31. } \\ 73 & \text { Ibid., 32. } \\ 74 & \text { Ibid., 33. } \\ 75 & \text { Ibid., 35. } \\ 76 & \text { Ibid., 36. } \\ 77 & \text { Ibid., 40. }\end{array}$




\section{James Alexander}

What this definition shares with all the others is that it is an exploration of the Aristotelian criterion. Ruling and being ruled cancel each other out in 'politics', just as they do for Arendt, but since rulers and ruled continue to exist in the 'police' order we live in, 'politics' exists as the perpetual possibility of disrupting 'police'. It follows that politics cannot occur within the ordinary system of ruling and being ruled, as it can for Collingwood, Oakeshott or Schmitt. Nor can it exist wholly separately from them, as Arendt suggests. This is why Rancière, and others like him, have been particularly critical of Arendt. Badiou, in particular, has complained about Arendt's eagerness to associate politics with the exchange of opinions, saying, almost as Schmitt might, 'Debate is political only to the extent that it crystallises in a decision. ${ }^{78}$ But it should be noted that this fifth definition sees politics as posterior to ruling and being ruled, not prior to it, as Schmitt supposes. So, as Badiou puts it, repeating Rancière's view: 'The essence of politics is not the plurality of opinions, but the prescription of a possibility in rupture with what exists. ${ }^{79}$ Or, as another radical theorist, Zizek, suggests, politics 'involves a kind of short-circuit'. ${ }^{80} \mathrm{It}$ is worth quoting Badiou's warning that such a definition is not really a definition in a strict sense at all: 'Since every politics is a singularity, there can be no definition of politics. Every definition relates politics to something other than itself (in fact, most often to the State). ${ }^{81}$ But here we may still consider this part of an identifiable definition.

\section{A Definition of Politics}

In short, the five definitions show that politics has been defined in very different ways:

1. as a pure activity which is nothing to do with ruling and being ruled in any conventional sense;

2. as the activity of approving or disapproving of ruling, rulers and rules;

78 Alain Badiou, Metapolitics, trans. Jason Barker (London: Verso, 2005), 15 .

79 Ibid., 24.

80 Slavoj Zizek, 'The Lesson of Rancière' in The Politics of Aesthetics:

The Distribution of the Sensible, trans. Gabriel Rockhill (London: Continuum, 2004), 70.

81 Badiou, op. cit. note 78, 46. 
3. as all of the activities involved in ruling and being ruled and in mediating between the two;

4. as any activities which are a consequence of one fundamental decision about who is friend and who is enemy as these play out in any context of ruling and being ruled; and

5. as the deliberate interruption of the usual activities of ruling and being ruled.

Each definition clarifies a possible meaning of politics by singling it out. Arendt's is a pure theory of politics, Rancière's a pure theory turned in a polemical direction, Collingwood's the most complete theory, and Oakeshott's and Schmitt's partial in rather different ways.

Each supposes that politics has a surplus not found in mere ruling and being ruled. Arendt suggests that the surplus is an activity wholly separate from ruling and being ruled which is continuous and necessary for a properly human life, and which can be damaged by ruling and being ruled. Oakeshott suggests that the surplus is an activity wholly separate from ruling in which the ruled (and rulers when not ruling) deliberate about rule in order to express approval and disapproval in such a way that rulers are aware of this deliberation. Collingwood suggests that the surplus is found in the intensification of ruling and being ruled so that ruling, being ruled and relating ruling and being ruled to each other are all elements of a political order. Schmitt suggests that the surplus is found in an activity which is prior to all ruling and being ruled, although ruling and being ruled are in many respects dependent or consequent upon it: and this is the exceptional rather than regular activity of deciding who is friend and who is enemy. And Rancière suggests that the surplus is found in moments of resistance to or rupture in the regular order of ruling and being ruled: so it is neither separate from ruling and being ruled, nor a way of relating them so they become political, nor a fundamental activity from which ruling and being ruled derives, but is wholly antagonistic to ruling and being ruled.

These five definitions, of course, are not without oddities of various sorts, and on the face of it cannot be combined into a complete definition of politics. But I think that it is possible to sketch some sort of complete definition if we return to the Aristotelian criterion. This will involve the superimposition of logical forms which many modern philosophers will dislike and which many politicians would probably fail to understand. One of these is the tetralemma of Sextus and Nagarjuna; the other is the dialectic of Hegel and 
Pierce. One works in fours ( $\mathrm{x}$, not-x, $\mathrm{x}$ and not-x, neither $\mathrm{x}$ nor not-x), the other in threes (thesis, antithesis and synthesis). They are no more and no less than structural conveniences of argument. But I think both are necessary to make sense of the modern theories of politics we have studied here. In case anyone thinks I am setting up the evidence in order to justify my arguments I would like to draw attention that although in the original version of this argument I did mistakenly try to relate four modern theories of politics to the fourfold of a tetralemma, I do not do this here: since this is forbidden by the suggestion that politics and rule form separate orders. It was also impossible as soon as a fifth theory was considered alongside the other four since then it was no longer possible to make any simple association between the theories and the tetralemma.

Politics must be defined in terms of a criterion, which, since we no longer have the state (and the circularity of defining the state in terms of politics and the politics in terms of the state), is the Aristotelian criterion. This is my name for the fact that politics has some sort of relation to rule - a strange and perhaps paradoxical relation which is usefully sketched in the phrase Aristotle quoted, 'ruling and being ruled'.

I. THE ARISTOTELIAN CRITERION: Politics is an activity which necessarily has some sort of relation to the activities appropriate to ruling and being ruled.

The criterion has to be further specified, for politics appears to be the word for the transformation of simple rule, or ruling and being ruled, so that it becomes a higher order of what I have called ruling-andbeing-ruled. Politics is, explicitly, then not the same thing as ruling or being ruled. It is a surplus; or, to speak more exactly, it is an order which coincides or intersects with the order of ruling and being ruled in such a way that it interacts with it. It is distinct from mere ruling and being ruled for the reason that it postulates a nonhierarchical rather than a hierarchical relation between humans.

\section{THE ARISTOTELIAN CRITERION FUR'THER}

SPECIFIED: Politics is an activity associated with an order which is not itself derived from ruling and being ruled because it is non-hierarchical whereas ruling and being ruled is hierarchical: but it is an order which intersects in some way or other with the order of ruling and being ruled in such a way that ruling and being ruled is transformed, or understood in a different way.

Then the question is then how politics and ruling and being ruled interact. In an attempt to answer this question, I have considered five of 
the simplest and yet most original theories of politics of the last century. When we consider these theories together we see that the interaction between politics and ruling and being ruled is manifold, but that these five theories between them suggest three ways that the interaction may occur. Politics may be separate from ruling and being ruled (according to Arendt), may be supportive of ruling and being ruled (according to Oakeshott, Collingwood and Schmitt), and may be subversive of ruling and being ruled (according to Rancière). In short, the non-hierarchical order may be separate from, support or subvert the hierarchical order. It is worth stating this clearly.

\section{THE RELATION OF POLITICS TO RULE:}

1. Politics may be separate from ruling and being ruled.

2. Politics may be supportive of ruling and being ruled.

3. Politics may be subversive of ruling and being ruled.

This threefold is a sort of primitive dialectic. Without this sort of dialectic there would simply be no way of relating any theory of politics which says politics is subversive of rule and any theory of politics which says it is supportive of it.

At this point there are several things to be observed. Theories of politics which say that politics is supportive of ruling and being ruled are, or seem, fairly simple: at least they do not present any radical difficulty. For they just ask us to ask how politics supports ruling and being ruled - which may be in the way Schmitt, Collingwood, or Oakeshott suggest, or in some other way. But a radical difficulty emerges when we consider a theory like Arendt's which says politics is wholly separate from ruling and being ruled or a theory like Rancière's which says politics is wholly subversive of ruling and being ruled. For these, and perhaps especially the first, seem to damage the Aristotelian criterion, which demands that politics be somehow related to ruling and being ruled. It is this which makes the form of logic associated with the tetralemma necessary, since it enables us to see an actual absence as a theoretical presence. This logic enables us to posit that a theory like Arendt's presupposes the existence of the thing it denies or excludes, namely, ruling and being ruled, because it is theoretically dependent on a negation of or transformation of ruling and being ruled. And, at this point, there is something else to be said, which is why, of the five theories I have considered, Rancière's has to be excluded from the next step in the argument. Rancière's theory is, I would argue, a 


\section{James Alexander}

polemical version of Arendt's theory, where a concept of ruling-andbeing-ruled is first separated from ruling and being ruled and then polemically turned against it, so politics and police are brought into conflict. Although the use of theory is very different, they both depend on pure or perfect ideas of politics.

So the threefold consideration that politics may be separate from, supportive of or subversive of ruling and being ruled is not a problem. The subversive theory is, I would argue, a polemical use of the separate theory, and the separate theory is not a theory which is structurally separate from what it claims to be separate. In order to be a theory of politics at all, it has to be theorisable in terms of a relation to a non-hierarchical order. If it were not then it would not be a theory of politics, but of something else - of conversation, perhaps.

So far we have the supposition that politics is an activity associated with the interaction between a non-hierarchical and a hierarchical order: where the interaction is expressed in some sort of surplus which transforms mere ruling and being ruled so it becomes ruling-and-being-ruled. A tetralemma suggests that there are four partial activities which can be called politics and which, taken together, are exhaustive:

\section{FOUR FORMS OF POLITICS:}

i. A political activity (of 'ruling-and-being-ruled') which is manifest in neither ruling nor being ruled (such that it is more than merely neither ruling nor being ruled).

ii. A political activity (of 'ruling-and-being-ruled') which is manifest in ruling (such that it is more than merely ruling).

iii. A political activity (of 'ruling-and-being-ruled') which is manifest in being ruled (such that it is more than merely being ruled).

iv. A political activity (of 'ruling-and-being-ruled') which is manifest in both ruling and being ruled (such that it is more than merely ruling and being ruled).

Each of these is a sort of activity which can be considered political. In each case, it is important to recall that what makes the activity political is not that it is merely any activity associated with 'neither ruling nor being ruled', or 'ruling', or 'being ruled', or 'both ruling and being ruled': but that it is a surplus form of activity which transforms mere 'ruling and being ruled' so it becomes in some way or to some extent 'ruling-and-being-ruled'. The first of the four may appear not to have any relation to ruling and being ruled; but once we 
remember the Aristotelian criterion that politics is, even if through negation, necessarily related to ruling and being ruled, and that 'ruling-and-being-ruled' in Aristotle's intensified sense was interpreted by Arendt to mean 'neither ruling nor being ruled', then there is no difficulty. Three of the four forms were theorised almost exactly in the twentieth century: the first by Arendt, the third by Oakeshott, and the fourth by Collingwood. Schmitt's concept of the political is not a theory of rule, and in fact does not really fit into this fourfold at all. But this is for the good reason that his was a theory of 'the political' and not politics as such. Yet even he laid emphasis on decision. For our purposes, and leaving grand theories of politics to one side for a moment, it is at least casually wholly necessary to recognise that one of the most basic meanings of politics is that it is what politicians do, which is, namely, rule. Of course, it must be understood that political rule is not mere rule because, as I said before, and as Oakeshott and Arendt were clearly right to emphasise, politics is not rule. So politics, as an activity associated with ruling is not mere ruling, but is, as in all the other cases, a surplus added to the activity of rule so it is transformed and becomes political.

In an earlier version of this paper, I called the four forms of politics conversation, command, commentary and co-ordination. There is some poetry in these terms, although I do not insist on them, and I only retain them here because I think that each form should be named. The names are by no means perfect. Perhaps some sort of Oakeshottian Latinity would do the work better, but I leave that to others. So we have, in mnemonical form:

\section{FOUR FORMS OF POLITICS NAMED:}

i. Conversation (a political activity which is wholly non-hierarchical, and has nothing to do with mere ruling or being ruled).

ii. Command (a political activity which is ruling in cognisance of the non-hierarchical political order which intersects with the hierarchical ruling order).

iii. Commentary (a political activity which is reciprocal to rule in the sense that it is the public expression of approval or disapproval of the hierarchical order in terms of the values of a non-hierarchical order).

iv. Co-ordination (a political activity which is the sum of all the attempts to transform a hierarchical order so it becomes a nonhierarchical order - an end which is impossible and yet is a teleological necessity; therefore, an activity which is, in a more 


\section{James Alexander}

pragmatic understanding, the sum of all the activities which relate the necessities of living in a hierarchical order to the imaginative possibilities of living in a non-hierarchical order).

This tetralemmic fourfold can be put into a dialectical threefold, when we consider the insistence of the Aristotelian criterion that politics be concerned with ruling and being ruled together. The second and third of the four are necessarily forms of activity which are conscious of the other side - rulers conscious of the ruled being ruled and the ruled conscious of rulers ruling - but both are onesided, and do not have completion in themselves as the first and fourth do. So we can then say that the second and third could be put together as the unstable second stage in a three-stage dialectic, which is properly Hegelian.

When they are put in dialectical relation to each other we have a complete definition of politics:

VI. A COMPLETE DEFINITION OF POLITICS: Politics is the activity which:

a. exists subjectively, ideally or in the abstract (when it is wholly unrelated to a hierarchical order of ruling and being ruled) as conversation;

b. exists objectively, actually or in the concrete (when it is in tension with a hierarchical order of ruling and being ruled) as an unresolved conflict of command and commentary; and

c. exists absolutely, or, as we might say, 'in the actuality of the idea' (when it is harmonised with hierarchical order of ruling and being ruled), as co-ordination.

This is far from being a dogmatic definition. It is a capacious one, and yet one with enough inner differentiation to be sensitive both to the various theories of politics we find in the writers of the last century and to philosophical necessity now. It is, in addition, the end point of an experiment in thought.

JAMES ALEXANDER (jalexand@bilkent.edu.tr) teaches in the Department of Political Science at Bilkent University, Ankara. His recent publications include 'Oakeshott as Philosopher' in The Cambridge Companion to Oakeshott (2012) and 'The Contradictions of Conservatism' in Government and Opposition (2013). 